\title{
Ochrona przeciwpożarowa w Toruniu w świetle ustawodawstwa wilkierzowego (XIII-XVI w.)
}

Pawel Mateusz Modrzyński*

W czasach średniowiecznych i wczesnonowożytnych władze miejskie starały się uregulować wiele aspektów życia miejskiego, w tym również kwestie związane z pożarnictwem. Miasta, w których dominowało budownictwo drewniane bądź drewniano-ceglane, były szczególnie narażone na pożary - gwałtowne, szybko się rozprzestrzeniające i obfitujące $\mathrm{w}$ wiele ofiar. Zwiększająca się liczba ludności, ciasna zabudowa i brak wolnej przestrzeni sprzyjały temu zagrożeniu. W wieku XVI w Prusach Książęcych, jak i w Prusach Królewskich, kwestie przeciwpożarowe (zwłaszcza w ustawodawstwie wilkierzowym) stopniowo zyskiwały na znaczeniu. Budownictwo miejskie było coraz bardziej kontrolowane przez Radę Miejską ${ }^{1}$. W Toruniu (podobnie jak

\footnotetext{
* Autor jest absolwentem kierunku historia na Uniwersytecie Mikołaja Kopernika w Toruniu. W roku akademickim 2015/2016 rozpoczął studia doktoranckie na Wydziale Nauk Historycznych UMK. W ramach doktoratu zajmuje się prawnokulturowymi aspektami funkcjonowania zwierząt w miastach pruskich (XIII-XVI w.). Dysertację doktorską przygotowuje pod opieką dr. hab. Piotra Olińskiego, prof. UMK. Jego zainteresowania badawcze skupiają się na: prawie chełmińskim i prawie lubeckim; regulacjach prawnych dotyczących życia codziennego (w tym prawie budowlanym i przepisach przeciwpożarowych); aspektach symbolicznych prawa karnego; związkach człowieka $\mathrm{z}$ fauną, florą oraz innymi elementami środowiska przyrodniczego (m.in. klimatu) w okresie od XIII do XVI w.

${ }^{1}$ Zob. P. M. Modrzyński, „Prawo budowlane” $w$ teorii prawa miejskiego doby późnego średniowiecza i epoki renesansu. Szkic historyczno-prawny, [w:] Doktoranc-
} 
w Chełmnie) w tym czasie przybywało prawnych zasad normatywnych. Toruń wraz z Chełmnem stanowiły kolebkę prawa chełmińskiego, co zapewne było nie bez znaczenia dla różnych rozważań nad stosowanym prawem i sprzyjało wprowadzaniu nowych regulacji normatywnych ${ }^{2}$. W niniejszym artykule zostaną przedstawione prawne aspekty funkcjonowania ochrony przeciwpożarowej $\mathrm{w}$ Toruniu $\mathrm{w}$ czasach średniowiecznych i w początkach czasów nowożytnych. Przytaczane niżej porównania $\mathrm{z}$ zasadami prawnymi stosowanymi $\mathrm{w}$ Chełmnie są o tyle zasadne, że $\mathrm{z}$ jednej strony oba miasta miały wspólne korzenie norm prawnych nie tylko $\mathrm{w}$ znaczeniu prawnym, ale również $\mathrm{w}$ znaczeniu historycznym, tzn. zaczęły je stosować w tym samym czasie i w takich samych okolicznościach. Z drugiej jednak strony późniejszy, odmienny rozwój obu miast pozwoli wskazać na to, w jakim stopniu charakter miasta wpływał na specyfikę stosowanego prawa, w tym przypadku związanego z ochroną przeciwpożarową. Dodajmy jeszcze, że problem ten, jak dotąd, nie cieszył się większym zainteresowaniem ${ }^{3}$.

Władze miejskie Torunia wydawały wiele wilkierzy, z których tylko kilka dotrwało do naszych czasów ${ }^{4}$. Już najstarszy zachowany wilkierz sporządzony około 1300 r. dla Nowego Miasta Torunia za-

kie spotkania z historia, red. M. Klempert, K. A. Kierski, S. Nowakowski, Olsztyn 2016, s. 19-28. Na temat budownictwa w Prusach zob. M. Arszyński, Organizacja i technika średniowiecznego budownictwa ceglanego w Prusach $w$ kontekście europejskim, Malbork 2016.

${ }^{2} \mathrm{~W}$ XV w. coraz większe znaczenie zyskiwał Toruń, gdzie opracowywano kolejne kodeksy prawa chełmińskiego. Chełmno ostatecznie straciło na znaczeniu w kwestii ustawodawstwa po wojnie trzynastoletniej, kiedy to sąd wyższy prawa chełmińskiego przeniesiono do Torunia.

${ }^{3}$ Problem ten, jak dotąd, przedstawił dość ogólnikowo Tadeusz Maciejewski; zob. T. Maciejewski, Wilkierze miasta Torunia, Poznań 1997, s. 93-94; istnieje też monografia dotycząca dawnego pożarnictwa: M. Zajęcki, Instrumenty prawne ochrony przeciwpożarowej w miastach Polski przedrozbiorowej, Poznań 2014. Jest to bardzo ogólnikowa, zbyt łatwo generalizująca wiele zagadnień monografia $\mathrm{z}$ poważnymi brakami w zakresie krytyki wykorzystanych źródeł, jak i ich pełnego wykorzystania. Np. ze źródeł toruńskich autor wykorzystał jedynie wilkierz Nowego Miasta Torunia z około 1300 r., pomijając zupełnie inne wilkierze toruńskie.

${ }^{4} \mathrm{~T}$. Maciejewski, Zbiory wilkierzy w miastach państwa zakonnego do $1454 \mathrm{r}$. i Prus Królewskich lokowanych na prawie chetmińskim, Gdańsk 1989; tenże, Wilkierze miasta Torunia. 
wiera liczne regulacje przeciwpożarowe, w tym przepisy dotyczące obowiązku gaszenia pożarów i kar za uchylanie się od tego obowiązku. Unikanie lub odmowa gaszenia pożarów były uznawane w prawie chełmińskim za przestępstwo przeciwko społeczności miejskiej ${ }^{5}$. Mieszczanie zobowiązani byli do pomocy w przypadku pożaru pod karą jednej grzywny ${ }^{6}$. Gdy mieszczanin zauważył pożar, powinien zaalarmować społeczność miejską ${ }^{7}$. Kara za uchylenie się od tego obowiązku była także równa jednej grzywnie. Odmowa gaszenia pożaru miała być karana dziesięcioma grzywnami ${ }^{8}$. W innym artykule ustanowiono, iż karę dziesięciu grzywien miano nakładać również na tych, którzy chowali się w swoim domu, aby uciec od obowiązku gaszenia pożaru?

Ustalono także kwestie związane ze sprzętem przeciwpożarowym. Mieszczanie, według wilkierza, powinni być zaopatrzeni w wiadro i siekierę ${ }^{10}$. Niespełnianie tego obowiązku miało być karane jednym wiardunkiem. Ponadto mieszczanie powinni posiadać również drabi$n^{11}{ }^{11}$. Byli też zobowiązani do trzymania wody w beczce ${ }^{12}$. Niestosowanie się do tego przepisu karane było czterema szelągami. Jeżeli woda ta została użyta niezgodnie $\mathrm{z}$ przeznaczeniem (czyli w innym celu, niż do gaszenia pożarów), właścicielowi beczki groziła nawet kara śmierci ${ }^{13}$.

Ważną częścią przepisów pożarowych były sprawy dotyczące pomocy poszkodowanym, jak i nagród wypłacanych za szybką pomoc w gaszeniu pożarów. Miasto starało się pomagać materialnie pogorzelcom $^{14}$. W wilkierzu Nowego Miasta Torunia z około 1300 r. od-

\footnotetext{
${ }^{5}$ T. Maciejewska, Przestępstwa przeciwko miastu w prawie Prus Królewskich, [w:] Gdańskie studia prawnicze, t. 19, 2008, s. 41-42.

${ }^{6}$ G. Bender, Die ältesten Willküren der Neustadt Thorn (c. vom Jahre 1300). Ein Beitrag zur altpreussischen Rechtsgesichte, Zeitschrift des Westpreussischen Geschichtsvereins, H. 7, 1882, art. 2, s. 106.

${ }^{7}$ Ibid., art. 3, s. 106

${ }^{8}$ Ibid., art. 5, s. 106.

${ }^{9}$ Ibid., § 14, s. 110.

${ }^{10}$ Ibid., $\$ 14$, s. 110.

${ }^{11}$ Ibid., § 55, s. 115.

12 Ibid., $\$ 15$, s. 110 .

${ }^{13}$ Ibid., § 16, s. 110.

${ }^{14}$ Ibid., art. 4, s. 106
} 
najdujemy artykuł, który mówi, iż miasto będzie wypłacać ofiarom pożaru sumy równe 1/4 oszacowanych strat. Wszyscy, którzy pomagali przy gaszeniu pożaru, mieli otrzymać wynagrodzenie od Rady Miejskiej, przy czym nie podano tutaj konkretnych $\operatorname{sum}^{15}$. Z kolejnych artykułów wynika, iż nagradzano tego, kto na miejsce pożaru pierwszy przyniósł beczkę wody. Zapewne istniały również wypłaty za kolejne beczki.

Następna grupa przepisów w wilkierzu Nowego Miasta Torunia z około 1300 r. dotyczyła przechowywania drewna. Stosy drewna, które miały być przeznaczone na opał czy też na budowę, mogły się stać potencjalnym źródłem ognia. Ustawodawstwo wilkierzowe zwracało szczególną uwagę na ową kwestię. Przepisy regulujące przechowywanie drewna na terenie miasta możemy znaleźć prawie we wszystkich wilkierzach miast pruskich ${ }^{16}$. Władze miejskie Nowego Miasta Torunia uchwaliły, że nie wolno było trzymać drewna w domu lub na ulicy ${ }^{17}$. Drewno powinno leżeć ułożone podłużnie, a nie $\mathrm{w}$ stosach pionowych ${ }^{18}$. Niezastosowanie się do takiego rozporządzenia groziło postawieniem pod pręgierzem (co wskazuje na możliwość zasądzenia kary hańbiącej bądź nawet cielesnej). Karę jednego wiardunku nakładano na osoby, które kupowały drewno związane w takie stosy.

Przepisy przeciwpożarowe wiązały się również z regulacjami budowlanymi. Ograniczano budowę domów w ogrodach ${ }^{19}$. Zabudowania w ogrodach były najczęściej drewniane, stwarzały zatem zagrożenie pożarowe. Obawy te można dostrzec w przepisach budowlanych, które mogły odnosić się do przepisów przeciwpożarowych. Zauważalne są elementy prawa sąsiedzkiego, które zmuszało mieszczan do pomocy w budowie domu swojego sąsiada ${ }^{20}$ Ówczesne budynki mieszkalne (i nie tylko) miały bowiem części wspólne, na przykład ścianę, która

\footnotetext{
${ }^{15}$ Ibid., art. 6, s. 106.

${ }^{16}$ T. Maciejewski, Zbiory wilkierzy w miastach państwa zakonnego.

${ }^{17}$ Ibid., § 36, s. 113.

${ }^{18}$ Ibid., § 37, s. 113.

${ }^{19}$ Ibid., $\S 31$, s. 112 ; intencje wydania tej regulacji nie są do końca jasne i budzą wiele wątpliwości.

${ }^{20}$ Ibid., $\S 53$, s. 115 .
} 
była jednocześnie murem grodzi-żarowym ${ }^{21 .}$ Być może więc ów obowiązek pomocy wynikał także z konieczności budowy części wspólnych.

Kolejny wilkierz z roku 1523 (zgodnie z ustaleniem T. Maciejewskiego w rzeczywistości z 1524 r.) nie zachował się. Treść owego wilkierza można jednak zrekonstruować na podstawie późniejszego wilkierza z $1595 \mathrm{r}^{22}$ dzięki notatkom znajdującym się po lewej stronie, przy nagłówkach poszczególnych artykułów ${ }^{23}$. Notatki te sugerują, iż duża część wilkierza z 1523 r. pokrywała się z późniejszym wilkierzem z 1595 r. Wilkierz z 1595 r. zawiera wiele przepisów przeciwpożarowych, które różnią się $\mathrm{w}$ pewnym stopniu od tych zawartych w wilkierzu Nowego Miasta Torunia z około $1300 \mathrm{r}$.

W wilkierzu z 1595 r. znajdują się informacje dotyczące nie tylko miasta, ale również, co ciekawe, pastwisk podmiejskich ${ }^{24}$. Przy zwierzętach na pastwiskach przebywali pasterze. Wypas mógł trwać bardzo długo. Pasterze przygotowywali potrawy na pastwiskach, rozpalając przy tym ogniska, które niepilnowane mogły spowodować pożar. $\mathrm{Z}$ innych kodeksów prawnych wiadomo, iż pasterze znani byli z tego, że nieostrożnie i nieodpowiedzialnie obchodzili się z ogniem ${ }^{25}$. Również Rada toruńska zabroniła pod groźbą kary rozpalania ognisk zarówno na pastwiskach, jak $\mathrm{i} \mathrm{w}$ lasach $^{26}$. W przypadku zauważenia ognia przez pasterzy mieli oni zagnać zwierzęta do zagrody (bądź na

${ }^{21}$ P. M. Modrzyński, „Prawo budowlane”, s. 22; M. Zajęcki, op. cit., s. 169-172.

${ }^{22}$ Archiwum Państwowe w Toruniu, Akta miasta Torunia (dalej cyt. APT, AmT), kat. II, I-4 (w dalszych przypisach podaję obie paginacje - nową i w nawiasie dawną). Wilkierz ten tylko udaje wilkierz z 1523/1524 r.

${ }^{23}$ Artykuły numer 23,41 i 82 z wilkierza z 1595 r. miały się zgadzać odpowiednio $\mathrm{z}$ artykułami 11, 83 i $85 \mathrm{w}$ wilkierzu z 1523/1524 r.

${ }^{24}$ APT, AmT, kat. II, I-4, art. 23, k. 23 (20).

${ }^{25}$ Znamy kodeksy prawa bartnego $\mathrm{z}$ terenów Pomorza $\mathrm{z}$ czasów nowożytnych, które zabraniają wnoszenia ognia przez pasterzy do lasu - G. Labuda, Nieznany pomnik polskiego prawa bartnego na Pomorzu, Rocznik Gdański, t. 14, 1955, art. 9, s. 359. O pomorskim prawie bartnym z czasów nowożytnych zob. P. M. Modrzyński, Symbolika kar $w$ dawnym prawie bartnym, [w:] Historia $w$ drodze ku przyszłości. XXIII Ogólnopolski zjazd historyków studentów, Torun 21-25 IV 2015, t. 1, red. M. Zmudziński, Torun 2016, s. 79-90; G. Szelęgowska, W. Nowosad, Święta pszczoła. Rzecz o pszczelarzeniu, Torun 2006, 73-81. Tezę tę potwierdzają również wilkierze innych miast, które zwracały uwagę na pasterzy jako potencjalnych podpalaczy.

${ }^{26}$ APT, AmT, kat. II, I-4, art. 23, k. 23 (20). 
teren miasta lub przedmieść miejskich ${ }^{27}$ ) przez drogę otoczoną ostrokołem. Gdyby zwierzęta wyczuły dym, mogłyby spanikować i rozbiec się po pastwisku. Droga $\mathrm{z}$ ostrokołem miała zapobiec rozproszeniu stada gnanego przez pasterzy.

Wilkierz z 1595 r. wprowadził regulacje dotyczące murów grodziżarowych $^{28}$. To duża zmiana $\mathrm{w}$ stosunku do poprzedniego wilkierza z około 1300 r., w którym owych regulacji w sposób bezpośredni jeszcze nie zawarto. Mury grodzi-żarowe oddzielały poszczególne budowle i skutecznie zapobiegały rozprzestrzenianiu się ognia $\mathrm{z}$ budynku na budynek $^{29}$. Jeżeli mieszczanin zauważyłby mury grodzi-żarowe $z$ drewna bądź „przylegające do siebie”(,,sklejone”) miał zawiadomić pana kwartalnego i wskazać mu to miejsce ${ }^{31}$. Mur grodzi-żarowy miał być według prawa stawiany przez obu sąsiadów ${ }^{32}$. Zwracano zatem uwagę, by sługa miejski nie burzył całego muru, jeżeli z drugiej strony nie zauważono oznak niszczenia. Przepis ten wydano w tym celu, aby drugi sąsiad, który dbał o swoją stronę muru, nie poniósł z powodu czyjejś niedbałości dodatkowych kosztów.

W wilkierzu z $1595 \mathrm{r}$. w kontekście przepisów przeciwpożarowych zwrócono również uwagę na rzemieślników. Wielu z nich wykorzystywało bowiem ogień i paleniska w trakcie swojej pracy. Zaniedbanie mogło skończyć się dla miasta tragicznie. Przestrzegano zatem słodowników, browarników i piekarzy przed spowodowaniem pożaru ${ }^{33}$. Wykorzystywali oni w swojej pracy kotły, piece i inne formy palenisk. W przypadku, gdyby rozniecili ogień, który poczynił straty materialne, mieli być ukarani karą dziecięciu grzywien.

\footnotetext{
${ }^{27}$ Tam znajdowały się stałe zagrody, gdzie trzymano zwierzęta w okresie zimowym.

${ }^{28}$ APT, AmT, kat. II, I-4, art 41, k. 36 (33)

${ }^{29}$ Nakaz budowy murów grodzi-żarowych był elementem ówczesnego prawa magdeburskiego i funkcjonował także w innych miastach, np. w Poznaniu - P. M. Modrzyński, ,,Prawo budowlane”, s. 22.

${ }^{30}$ Prawdopodobnie niektórzy mogli próbować zaoszczędzić na materiale budowlanym.

${ }^{31}$ APT, AmT, kat. II, I-4, art 41, k. 36 (33).

${ }^{32}$ P. M. Modrzyński, ,, Prawo budowlane”, s. 22.

${ }^{33}$ APT, AmT, kat. II, I-4, art. 41, k. 36 (33)-37 (34).
} 
W wilkierzu tym pojawił się również artykuł dotyczący przechowywania drewna, desek, węgla, słomy i siana ${ }^{34}$. Artykuł ten jest modyfikacją regulacji z wilkierza Nowego Miasta. Jest on jednak o wiele obszerniejszy i wprowadza nowe zakazy. Postanowiono więc, iż nikt nie powinien trzymać drewna na własne potrzeby (bez względu na to, czy miało być przeznaczone na opał, czy też wykorzystane do pracy) na ulicach lub na własnych podwórkach. Tak jak w poprzednim wilkierzu (z około 1300 r.), zawarto nakaz układania drewna podłużnie, a nie w pionowych stosach. Stosy takie błyskawicznie mogły się zająć ogniem. Jeżeli drewno musiało leżeć w stosie, należało położyć je na półżelaznym stojaku. W przypadku zaprószenia ognia stojak taki zapewniał izolację. Ograniczano również ilość kupowanego drewna. Mieszczanie powinni kupować drewno tylko na własny użytek, a nie na dalszą odsprzedaż. Drewno powinno leżeć w piwnicy. Określono przy tym konkretną ilość, jaką można było trzymać w piwnicach. Zakazywano przechowywania słomy i siana o wartości większej niż cztery grzywny. Zaznaczono, iż nie wolno zagracać pomieszczeń mieszkalnych.

Poświęćmy nieco uwagi podobieństwom i różnicom przepisów przeciwpożarowych stosowanych w Toruniu i w Chełmnie. Najstarszym zachowanym wilkierzem chełmińskim jest wilkierz z około $1400 \mathrm{r}^{35}$ Znalazły się w nim przepisy odnoszące się do kwestii finansowych w przypadku strat w wyniku pożaru. Mieszczanin, w którego domu wybuchł pożar, zobowiązany był do zapłaty odszkodowania sąsiadowi, który w wyniku tego pożaru doznał szkó $\mathrm{d}^{36}$. W wilkierzach toruńskich takiego przepisu nie było. W Chełmnie mieszczanie byli zobowiązani również do pomocy w odbudowie spalonego domu. Pomoc ta nie przysługiwała jednak w przypadku, gdy pożar objął kolejne domy. W toruńskich regulacjach takiej zasady nie zapisano. W Chełmnie za pomoc w gaszeniu pożaru miasto miało wypłacać nagrody. Owe gratyfikacje wypłacano za zwożenie wody do pożaru. Miano płacić jednego skojca za każdą furę z czterema końmi. Zaznaczono, że nagroda ta nie obo-

\footnotetext{
${ }^{34}$ APT, AmT, kat. II, I-4, art. 82, k. 69 (64)-70 (65).

${ }^{35}$ A. Semrau, Die Willkür der Stadt Kulm von etwa 1400, Mitteilungen des Coppernicus-Vereins für Wissenschaft und Kunst zu Thorn, H. 35, 1927, s. 29-58.

${ }^{36}$ Ibid., art. 4, s. 37.
} 
wiązuje w przypadku wożenia wody ze studni targowych. W przypadku wykorzystywania wody $\mathrm{z}$ takich studzien płacono jednego szeląga za każdą furę (zaprzężoną w cztery konie). Podobnie było w Toruniu, przy czym tutaj zasady donoszenia wody, jak i wysokość nagród były uregulowane bardziej precyzyjnie.

W wilkierzu chełmińskim z około 1400 r. nie zawarto wielu informacji dotyczących sprzętu przeciwpożarowego. Przepisy takie znajdowały się już w pierwszym wilkierzu toruńskim (Nowego Miasta, z około 1300 r.). W przypadku Chełmna zaznaczono jednak, że przy gaszeniu pożaru nie wolno było wykorzystywać mieczy i wideł (tu jako broń) ${ }^{37}$. Był to zapewne wyraz troski władz miasta o broń mieszczan, którą według prawa każdy obywatel powinien posiadać ${ }^{38}$. Być może chciano uniknąć również tego, aby mieszczanie $\mathrm{w}$ gniewie nie użyli owej broni przeciwko sobie w czasie gaszenia pożaru. Wybuch pożaru był tragedią, o którą mieszczanie czy też sąsiedzi mogli obwiniali się nawzajem. Regulacji takich nie było w wilkierzach toruńskich. W trakcie pożaru i chaosu, jaki ze sobą ten żywioł niósł, mogło również dochodzić do szabrownictwa ${ }^{39}$. Mieszczanie mogli próbować bronić swojego dobytku. Wilkierzowe przepisy chełmińskie postanawiały także, iż każdy mieszczanin powinien posiadać $\mathrm{w}$ domu długą drabinę $^{40}$. Przepisy toruńskie znane z około 1300 r. są w tym zakresie pełniejsze.

W wilkierzu chełmińskim z około $1400 \mathrm{r}$. znalazły się również regulacje dotyczące przechowywania tak drewna, jak i materiałów łatwopalnych. Według wilkierza nie wolno było na podwórzu składować kłód drewna dłuższych niż pół pręta ${ }^{41}$. W przypadku nadwyżki drewna mieszczaninowi nadmiar ów odbierano. Drewno miało być także rekwirowane w przypadku, gdy leżało przy rowie/fosie w pobliżu

\footnotetext{
${ }^{37}$ Ibid., art. 4, s. 37.

${ }^{38}$ Podobne regulacje dotyczące zakazów zabierania ze sobą broni do gaszenia pożarów spotykamy również w innych miastach, np. w Poznaniu - Wilkierze poznańskie. Część I - Administracja i sądownictwo, opr. i wyd. W. Maisel, WrocławWarszawa-Kraków 1966, nr 14, s. 6.

${ }^{39}$ M. Zajęcki, op. cit., s. 265-269.

${ }^{40}$ A. Semrau, op.cit, art. 4, s. 37.

${ }^{41}$ Ibid., art. 5, s. 37.
} 
muru. Zabraniano też przetrzymywania drewna na ulicach czy w pomieszczeniach mieszkalnych. Mieszczanie nie mogli składować siana $\mathrm{w}$ obrębie miasta $\mathrm{w}$ ilościach większych niż jedna fura ${ }^{42}$. Przypomina to regulacje znane $z$ Torunia. W Chełmnie nie wolno było również na terenie miasta składować mierzwy bez potrzeby ${ }^{43}$. Mierzwa była przede wszystkim zagrożeniem sanitarnym, ale także, jak już wcześniej wspominano, zagrożeniem pożarowym. Nakazywano wywozić ją z miasta poza jego bramy. Zakazano wywożenia mierzwy w miejsce określone pomiędzy bramą (,gemoltin Tore” - później „Fishertor”) a fosą. Niedozwolonym miejscem na jej zwożenie był również most.

W wilkierzu chełmińskim z około 1400 r. znalazła się jedna regulacja dotycząca ograniczania zabudowy drewnianej na rzecz ceglanej. Wszystkie nowo powstające budynki powinny mieć dachy pokryte dachówką, stare zaś, które były odnawiane, nie mogły mieć dachów pokrywanych strzechą czy słomą ${ }^{44}$. Podobne przepisy wydawano też w innych miastach pruskich i, jak się wydaje, była to wówczas ogólnie przyjęta norma.

W Chełmnie nakazywano także, aby gasić światła, zanim nastanie noc $^{45}$. Za światło uważano wszelki palący się ogień, w tym również ten w piecach. Dotyczyło to zwłaszcza piekarzy, słodowników i browarników, którzy ze względu na wykonywaną pracę mogli łatwiej zaprószyć ogień.

Następny znany wilkierz chełmiński z artykułami przeciwpożarowymi pochodzi z $1590 \mathrm{r} .{ }^{46}$ Według tego wilkierza mieszczan zobowiązano do posiadania odpowiedniego sprzętu przeciwpożarowego ${ }^{47}$. We wcześniejszym wilkierzu zwrócono uwagę tylko na drabinę. W skład owego sprzętu miały wchodzić: węborek, drabina, hak, siekiera lub sikawka, a także kłoda (miara objętości) wody ${ }^{48}$.

\footnotetext{
${ }^{42}$ Ibid., art. 10, s. 39.

${ }^{43}$ Ibid., art. 11 , s. 39.

${ }^{44}$ Ibid., art. 13a, s. 40.

${ }^{45}$ Ibid., art. 24, s. 44.

${ }^{46}$ Wilkierz z 1590 r. został wydany przez Z. Zdrójkowskiego - Z. Zdrójkowski, Nieznane źródta prawa chetmińskiego z XVI i XVII wieku. Część I, Czasopismo Prawno-Historyczne, t. 23, 1971, z. 2, s. 141-182.

${ }^{47}$ Ibid., art. 33, s. 155-156.

${ }^{48}$ Ibid., art. 34, s. 156.
} 
Tak jak w poprzednim wilkierzu, poruszono kwestie związane z nagrodami za pomoc przy gaszeniu pożarów. Miasto miało je wypłacać za noszenie wody. Za pierwszą beczkę, która została przyniesiona, płacono 25 groszy, za drugą 10 groszy, za trzecią zaś 5 szelągów ${ }^{49}$. Władze miejskie wydały rozporządzenie o studniach ${ }^{50}$. Kiedy woda $\mathrm{z}$ beczek się wyczerpała, mieszczanie mogli ją szybko zastąpić wodą ze studzien miejskich. W sumie miało być pięć studni. Kontrolę nad nimi sprawować mieli specjalnie do tego celu wyznaczeni urzędnicy.

W wilkierzu chełmińskim z 1590 r. zwrócono szczególną uwagę na materiały łatwopalne. Zakazano trzymania drewna na ulicach ${ }^{51}$. Zaznaczono, że drewno przeznaczone na budowę domu należy trzymać przed domem, tak aby ulica pozostała przejezdna. Dotyczyło to zwłaszcza ulic, które przylegały do murów miejskich ${ }^{52}$. Zagracone ulice należało niezwłocznie oczyścić ${ }^{53}$. Ulice miały być wolne od materiałów łatwopalnych pochodzących z odpadków rzemieślniczych ${ }^{54}$. Na okres zimowy ustanowiono, iż drewno ma być zwożone w okolicach wsi Podwiesk $^{55}$. Domy powinny zostać pokryte dachówką, a nie strzechą ${ }^{56}$. Władze miejskie wydały rozporządzenie, które zakazywało topienia łoju lub wyrabiania świec w kramach ${ }^{57}$. Topienie łoju polegało na gotowaniu tłuszczu. Do tego potrzebny był ogień, który w budach stwarzał ryzyko pożaru. W przepisach wilkierza chełmińskiego z $1590 \mathrm{r}$. odnajdujemy przepisy dotyczące zachowania czystości, sprzątania ulic, wywozu śmieci i nieczystości ${ }^{58}$. Zakazano trzymania tzw. skrzyń gnojowych. Gazy gnilne, które powstają w procesie rozkładu (np. odchodów), są łatwopalne ${ }^{59}$. Skrzynie takie, które pozbawione były wenty-

${ }^{49}$ Ibid., art. 33, s. 155-156.

${ }^{50}$ Ibid., art. 30, s. 155 .

${ }^{51}$ Ibid., art. 35, s. 156.

${ }^{52}$ Ibid., art. 84, s. 163.

${ }^{53}$ Ibid., art. 116, s. 169.

${ }^{54}$ Odpadki takie były wyrzucane wprost na ulicę - ibid., art. 72, s. 161.

${ }^{55}$ Z. Zdrójkowski, op. cit., art. 142, s. 173.

${ }^{56}$ Ibid., art. 38, s. 156.

${ }^{57}$ Ibid., art. 47, s. 158.

${ }^{58}$ Ibid., art. 69-70, s. 161.

${ }^{59}$ Gazy takie są dość poważnym problemem współczesnych kanalizacji. Problem ten rozwiązuje się poprzez wentylację w postaci włazów wylotowych. 
lacji, mogły po prostu wybuchnąć, gdy ktoś z pochodnią lub innym źródłem ognia otworzył taką skrzynię. W przypadku znalezienia takich skrzyń u mieszczanina, nakładano na niego karę w wysokości trzech grzywien oraz dodatkowo niszczono samą skrzynię ${ }^{60}$.

W chełmińskim wilkierzu z 1590 r., podobnie jak wilkierzu toruńskim z 1595 r., zwrócono uwagę na rzemieślników oraz na przepisy budowlane. Zakazano na terenie miasta „warzenia” smoły ${ }^{61}$. Zabraniano zdunom posiadania pieców do wypalania garnków ${ }^{62}$. Nakazano również, aby mieszczanie dbali o dobry stan kominów i dymników ${ }^{63}$. Kominy były w czasach późnego renesansu sprawą pierwszorzędną w przepisach przeciwpożarowych ${ }^{64}$; miały być „obwarowane”, co sugeruje zastosowanie jakiejś izolacji, prawdopodobnie ceglanej. W wilkierzu nie zawarto żadnych informacji o ograniczaniu zabudowy drewnianej. Być może miasto wspierało tę działalność. Istnieją jednak regulacje $\mathrm{z}$ owego wilkierza, które reglamentują ilość sprzedawanej cegły ${ }^{65}$, co wskazuje na to, że był to materiał budowlany deficytowy w Chełmnie $^{66}$.

Nie zauważamy, w odróżnieniu od regulacji miasta Torunia z końca XVI w., artykułów dotyczących przeciwdziałania pożarom na pastwiskach. Istnieje jedno rozporządzenie, które wspomina o rowach na pastwiskach $^{67}$. Rowy takie mogły służyć jako droga do pędzenia bydła z pola lub jako izolacja ogniowa pomiędzy poszczególnymi częściami pola.

Przepisy przeciwpożarowe są dobrym źródłem ukazującym schemat kształtowania się ówczesnej mentalności mieszczan. Troska o dobro wspólne, jak i wyrzeczenia, które za tym szły, były nieodłączną cechą

\footnotetext{
${ }^{60} \mathrm{O}$ podobnych skrzyniach mówią również przepisy miasta Torunia, APT, AmT, kat. II, I-95, k, 281.

${ }^{61}$ Z. Zdrójkowski, op. cit., art. 72, s. 161.

${ }^{62}$ Ibid., art. 87, s. 163.

${ }^{63}$ Ibid., art. 71, s. 161.

${ }^{64}$ Zob. M. Zajęcki, op. cit., 154-163. Kwestie związane z bezpiecznym funkcjonowaniem kominów zajęły sporo miejsca w wilkierzu miasta Tczewa z roku 1599.

${ }^{65}$ Z. Zdrójkowski, op. cit., art. 140, s. 173.

${ }^{66}$ Sugeruje to podniesienie ceny cegły dla obcych-nieobywateli. Cena mogła być też podwyższona, gdy cegielnia zmuszona była do kupna drewna spławowego, ibid., art. 148, s. 174; por. M. G. Zieliński, Chetmno. Civitas totus Prussiae metropolis XVIXVIII w., Bydgoszcz 2007, s. 51.

${ }^{67}$ Z. Zdrójkowski, op. cit., art. 110, s. 168.
} 
tworzenia się norm prawnoustrojowych średniowiecznych i wczesnonowożytnych społeczności miejskich. Zaznaczyć jednak trzeba, iż owe odgórne regulacje nie zawsze znajdowały zrozumienie wśród części mieszczan, zwłaszcza tych biedniejszych, którzy na owe wyrzeczenia nie mogli sobie po prostu pozwolić. Przepisy przeciwpożarowe w wilkierzach toruńskich i chełmińskich stanowiły pewien kanon, który funkcjonował aż do końca XVIII w. Średniowieczne przepisy, dość ogólnikowe, w epoce nowożytnej zostały zmodernizowane i sprecyzowane. Wiele artykułów przeciwpożarowych zostało poszerzonych. $\mathrm{Z}$ analizy wilkierzy i dokonanego porównania możemy wywnioskować, iż przepisy przeciwpożarowe w Toruniu i w Chełmnie były bardzo podobne. Oczywiście wynikało to ze „wspólnego"68 prawa chełmińskiego. Cechą wspólną i nieodłączną były obowiązek uczestnictwa mieszczan $\mathrm{w}$ akcjach pożarniczych, jak i określenie kar związanych $\mathrm{z}$ unikaniem owego obowiązku. W obu miastach zwrócono szczególną uwagę na przechowywanie materiałów łatwopalnych, a przede wszystkim na drewno. Podobny był także obowiązek przechowywania wody $\mathrm{w}$ beczkach na potrzeby gaszenia ewentualnego pożaru. Zarówno w Toruniu, jak i w Chełmnie wprowadzono obowiązek posiadania przez mieszczan sprzętu przeciwpożarowego. W obu miastach rady miejskie miały wypłacać nagrody tym, którzy wyróżnili się w akcjach pożarniczych, jak też pomagać pogorzelcom finansowo bądź w odbudowie zniszczonych domów. Kontrolowano również pracę rzemieślników.

Można jednak znaleźć pewne różnice w ustawodawstwie pożarniczym obu ośrodków. Otóż Toruń w przeciwieństwie do Chełmna ograniczał zabudowę drewnianą na rzecz murowanej. Wskazuje to jednoznacznie na charakter zabudowy w obu miastach. Nie można również wykluczyć, że w Toruniu duże znaczenie miały wcześniejsze doświadczenia. W Nowym Mieście przeważała zabudowa drewniana, co drastycznie zwiększało ryzyko pożarowe, tutaj też pożary wielokrotnie niszczyły całą zabudowę ${ }^{69}$. Być może właśnie $\mathrm{z}$ tego powodu

\footnotetext{
${ }^{68}$ Zwrócić należy uwagę w tym miejscu, iż prawo chełmińskie nie było jednolite i mogło być odmiennie stosowane w różnych ośrodkach.

${ }^{69}$ Zob. P. Oliński, Nowe Miasto Toruń w nowożytnych kronikach mieszczańskich, [w:] Nowe Miasto Toruń 750 lat od lokacji, red. K. Mikulski, P. Oliński, W. Rozynkowski, Toruń 2014, s. 244-271.
} 
przepisy przeciwpożarowe pojawiły się już w wilkierzu z $1300 \mathrm{r}$. Mogło to wpłynąć na zakaz używania drewna jako materiału budowlanego, co znalazło odzwierciedlenie $\mathrm{w}$ wydawanych przepisach. W Toruniu zwrócono uwagę również na pożary na pastwiskach podmiejskich. Chełmno takich regulacji nie wydało. Na przełomie średniowiecza i czasów wczesnonowożytnych hodowla zwierząt, ogrodnictwo i rolnictwo zwiększyły swoje znaczenie w gospodarce miejskiej Chełmna. Pastwiska znajdujące się poniżej położonego na wzniesieniu miasta nie stanowiły tam jednak wielkiego zagrożenia pożarowego.

\section{Bibliografia}

Źródła

Archiwum Państwowe w Toruniu, Akta miasta Torunia, kat. II, I-4.

Bender G., Die ältesten Willküren der Neustadt Thorn (c. vom Jahre 1300). Ein Beitrag zur altpreussischen Rechtgeschichte, Zeitschrift des Westpreussischen Geschichtsvereins, H. 7, 1882, s. 95-126.

Labuda G., Nieznany pomnik polskiego prawa bartnego na Pomorzu, Rocznik Gdański, t.14, 1955, s. 342-374.

Semrau A., Die Willkür der Stadt Kulm von etwa 1400, Mitteilungen des Coppernicus-Vereins für Wissenschaft und Kunst zu Thorn, H. 35, 1927, s. $28-58$.

Wilkierze poznańskie. Część I: Administracja i sądownictwo, opr. i wyd. W. Maisel, Wrocław-Warszawa-Kraków 1966.

Zdrójkowski Z., Nieznane źródła prawa chetmińskiego z XVI i XVII wieku. Część I, Czasopismo Prawno-Historyczne, t. 23, 1971, z. 2, s. 141-182.

Opracowania

Arszyński M., Organizacja i technika średniowiecznego budownictwa ceglanego w Prusach w kontekście europejskim, Malbork 2016.

Maciejewski T., Przestępstwa przeciwko miastu w prawie miast Prus Królewskich, Gdańskie Studia Prawnicze, t. 19, 2008, s. 33-46.

Maciejewski T., Wilkierze miasta Torunia, Poznań 1997.

Maciejewski T., Zbiory wilkierzy w miastach państwa zakonnego do $1454 \mathrm{r}$. i Prus Królewskich lokowanych na prawie chetmińskim, Gdańsk 1989.

Modrzyński P. M., „Prawo budowlane” w teorii prawa miejskiego doby późnego średniowiecza i epoki renesansu. Szkic historyczno-prawny, [w:] 
Doktoranckie spotkania z historia, red. M. Klempert, K. A. Kierski, S. Nowakowski, Olsztyn 2016, s. 19-28.

Modrzyński P. M., Symbolika kar w dawnym prawie bartnym, [w:] Historia w drodze ku przyszłości, t. 1, red. M. Zmudziński, Toruń 2016, s. 79-90.

Oliński P., Nowe Miasto Toruń w nowożytnych kronikach mieszczańskich, [w:] Nowe Miasto Toruń 750 lat od lokacji, red. K. Mikulski, P. Oliński, W. Rozynkowski, Toruń 2014, s. 244-271.

Szelęgowska G., Nowosad W., Święta pszczoła. Rzecz o pszczelarzeniu, Toruń 2006.

Zajęcki M., Instrumenty prawne ochrony przeciwpożarowej w miastach Polski przedrozbiorowej, Poznań 2014.

Streszczenie: W czasach średniowiecza wraz rozwojem prawa chełmińskiego miasta pruskie rozpoczęły kodyfikację przepisów przeciwpożarowych. Toruń jako przodujący ośrodek prawa chełmińskiego wydał wiele regulacji w kwestii pożarnictwa. Podobnie było w pobliskim Chełmnie. Owe regulacje zostały zawarte w wilkierzach miejskich. Przepisy przeciwpożarowe wprowadziły obowiązek uczestnictwa mieszczan w akcjach pożarniczych. Określono również sprzęt przeciwpożarowy, jaki mieszczanie powinni posiadać w domu. Ustalono nagrody dla mieszczan, którzy wyróżnili się przy gaszeniu pożarów. Miasto zobowiązało się także do udzielania pomocy finansowej pogorzelcom. Miasta wydały też wiele przepisów prewencyjnych. Zabraniano przetrzymywania materiałów łatwopalnych na terenie miasta - przede wszystkim drewna opałowego oraz siana. Miasta starały się wypierać zabudowę drewnianą na rzecz ceglanej. Nowe budynki musiały być oddzielone murami grodzi-żarowymi. Przepisy przeciwpożarowe powstałe w średniowieczu obowiązywały nadal w czasach nowożytnych. Regulacje były w miarę upływu czasu modyfikowane. Przejawiało się to w wydawaniu coraz bardziej szczegółowych i obszerniejszych przepisów wilkierzowych. Przepisy przeciwpożarowe były nieodłącznym elementem prawa chełmińskiego oraz czynnikiem kształtującym miasta średniowieczne, jak i wczesnonowożytne.

Fire protection in Torun in the light of the legal regulations passed by the city council (the $13^{\text {th }}-16^{\text {th }}$ centuries)

Abstract: During the Middle Ages, as the Chełmno Law evolved, the Prussian towns started to codify fire regulations. Torun, one of the most important centres of the Chełmno Law, issued many fire regulations; so did Chełmno. 
The regulations were included in the codes of law passed by the city council. Fire regulations made it obligatory for burghers to take part in fire rescue operations. They strictly defined fire prevention equipment which burghers were expected to keep at home. Special awards were established for burghers who extinguished fires outstandingly well. The city also obliged itself to help financially to fire victims. Both cities also issued many preventive regulations. It was forbidden to store inflammable objects in the city - it concerned mainly things made of firewood and hay. The cities tried to replace wood with brick. New buildings had to be separated with fire walls. Fire regulations were constantly updated, which was reflected in more and more detailed laws passed by the city council. Fire regulations constituted an indispensable element of the Chełmno Law and a factor which shaped the medieval and early modern city.

\section{Der Feuerschutz in Thorn im Licht der willkürlichen Gesetzgebung (XIII-XVI Jh.)}

Zusammenfassung: Parallel zur Entwicklung des Kulmer Rechts begannen die preußischen Städte im Mittelalter mit der Kodifizierung von Vorschriften zum Feuerschutz. Als führendes Zentrum des Thorner Rechts gab Thorn eine Reihe von Regelungen zum Feuerschutz heraus. Ähnlich war es im nahen Kulm. Beide Regelungen wurden in die städtischen Willküren aufgenommen. Die Brandschutzvorschriften führten eine Pflicht der Bürger zur Teilnahme an Feuerlöschaktionen ein. Sie legten auch fest, welche Feuerlöschgeräte die Bürger zu Hause haben sollten. Man setzte Preise für Bürger aus, die sich beim Löschen von Bränden auszeichneten. Die Stadt verpflichtete sich auch zu finanzieller Hilfe für Brandgeschädigte. Außerdem erließen die Städte viele vorbeugende Vorschriften. Die Lagerung von leichtbrennbaren Materialen auf dem Gebiet der Stadt wurde verboten, vor allem von Brennholz und Heu. Die Städte waren bemüht, den Holzbau zugunsten des Steinbaus zurückzudrängen. Neue Gebäude mussten mit brandsicheren Mauern abgeteilt sein. Die Brandschutzvorschriften aus dem Mittelalter waren auch noch in der Neuzeit in Kraft. Im Lauf der Zeit wurden die Regelungen modernisiert. Das äußerte sich in immer detaillierteren und ausführlicheren Vorschriften in den Willküren. Die Brandschutzvorschriften waren ein integraler Bestandteil des Kulmer Rechts und ein Faktor, der sowohl die mittelalterlichen als auch die neuzeitlichen Städte prägte. 
Słowa kluczowe: prawo chełmińskie, Toruń, Chełmno, przepisy przeciwpożarowe, wilkierze, średniowiecze, renesans

Keywords: Chełmno (Kulm) law, Toruń, Chełmno (Kulm), fire prevention regulations, wilkierz (codes passed by the city council), the Middle Ages, the Renaissance

Schlüsselwörter: Kulmer Recht, Thorn, Kulm, Brandschutzvorschriften, Willküren, Mittelalter, Renaissance 